\author{
Monika Podwórna \\ Dr inż. \\ Politechnika Wrocławska, Wydział \\ Budownictwa Lądowego i Wodnego \\ monika.podworna@pwr.edu.pl
}

DOI: 10.35117/A_ENG_19_11_02

\title{
Response of short span bridges under mooving high-speed train
}

\begin{abstract}
The paper presents a comparison of dynamic responses of bridges with different dynamic characteristics to a quasi-real mobile load. Different bridge - track - train (moving at high speed) systems were analyzed. The system is ballasted monotrack. The model of the bridge is a 15-meter beam simple-supported with a steel structure. The load model is represented by the Shinkansen train. The results are compared with very simplified load models, such as streams of concentrated forces, concentrated masses, one-mass oscillators and two-mass oscillators.
\end{abstract}

Keywords: Short span simply supported railway bridge; Vehicle-bridge interaction, Resonance

\section{Introduction}

Transport systems play a key role in modern societies. Economic development depends on the rapid and effective mobility of both people and goods. In this context, the high-speed rail system (HSR) is an attractive alternative to road transport. High-speed rail has become an important element of the national transport network, as it is a travel option that increases the quality of life and supports economic growth. HSR was established in the second half of the 20th century. In 1964, the pioneering HSR system was opened - the first section of the Japanese-Shinkansen train line (Tokyo-Osaka) moving at an operating speed of $210 \mathrm{~km} / \mathrm{h}$. Then in 1981, a railway line was created connecting Paris with Lyon, on which the TGV train moved with a maximum speed of $260 \mathrm{~km} / \mathrm{h}$. Italy joined Japan and France in 1981, Germany in 1988 (ICE trains), Spain in 1992, Belgium in 1997, Great Britain and China in 2003, Switzerland and South Korea in 2004, The Netherlands and Turkey in 2009, Austria in 2012 and Poland in 2015. Based on the data contained in the study of the European Union [19], Figure 1 shows the current state and lines in the construction of a high-speed rail system in Europe.

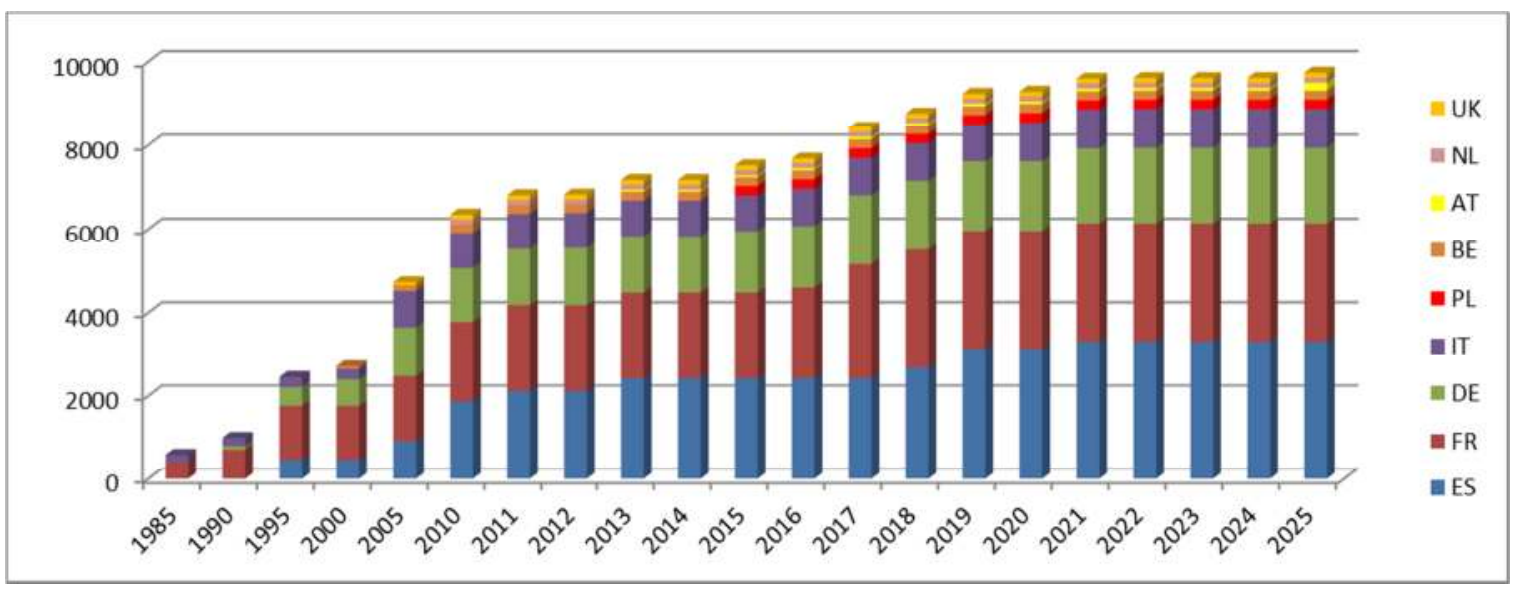

Fig. 1. The length of the HSR NETWORK high-speed rail line in Europe 
According to the European Union Directive [2], high-speed rail lines include:

- specially built high-speed lines, generally designed for speeds equal to or exceeding $250 \mathrm{~km} / \mathrm{h}$,

- specially upgraded high-speed lines for speeds of about $200 \mathrm{~km} / \mathrm{h}$,

- specially modernized high-speed lines, having special features resulting from conditions related to topography and urban planning, on which lines the speed must be adapted to each case. This category also includes lines connecting high-speed networks and conventional networks, lines running through stations, access to terminals, locomotives, etc., which are used by high-speed rolling stock running at conventional speed.

Bridge structures are very important elements of a high-speed rail line, they are used to cross obstacles such as rivers, valleys, existing highways or railways. In recent decades, the analysis of railway bridges has been the subject of research by many engineers, because the dynamic effect caused by trains crossing the bridge is one of the most important aspects that should be taken into account at the design stage [4]. Studies have shown that at speeds above $200 \mathrm{~km} / \mathrm{h}$, excessive vibration may occur as a result of resonance phenomena, which has been confirmed in standard regulations [11]. Transitions of successive loads (successive axle loads of wheelsets moving over the bridge) can excite the bridge structure and when the frequency of excitation (or its multiplicity) is close to the frequency of natural vibrations of the system (or its multiplicity) a resonance phenomenon may appear. This can lead to several problems, namely: instability of the bedding layer, loss of contact between the wheel and rail, increased damage due to fatigue or even passenger comfort. [20] It should be remembered that some aspects are not yet fully known, which causes designers to face the problem of dynamic analysis of railway bridges - whether there will be higher acceleration values than those recognized as acceptable in European standards [22].

Current European standards reflect the problem of excessive vibration by requiring dynamic analysis to be performed in almost every case where the maximum line speed exceeds $200 \mathrm{~km} / \mathrm{h}$. Compared to previous Polish Standards [12, 13], the PN-EN [10.11] standards expanded the approach to dynamic rail bridge issues. The dynamic nature of the load is taken into account in two ways:

- by introducing static calculations on loads increased by the dynamic factor $\varphi$ - just like in previous national standards,

- by analyzing the direct processes of deformation and distribution of internal forces and stresses from loads moving at set speeds based on the dynamic response of the system (time analysis) [26]

Due to the non-uniform requirements for high-speed rail, dynamic analyzes should be carried out based on standards, technical literature, and railway technical standards. [27] A bridge structure approved for use and operation at high speed rolling stock journeys should meet many conditions. The main ones are:

- ultimate limit state requirements, taking into account additional dynamic and fatigue effects caused by high speeds,

- the requirements of the serviceability limit state, which ensures traffic safety and adequate passenger comfort,

- structural durability requirements, avoiding permanent deformations,

- requirements for appropriate railroad equipment,

- the correctness of construction solutions, both design and executive, 
- environmental protection requirements - minimal pollution and noise,

- economic requirements - track operation and maintenance costs should be relatively low.

\section{Dynamic analysis}

The history of mobile load analysis in Poland dates back to pre-war times. The first pioneering works are connected with the name of Aleksander Wasiutyński. The use of computational methods for mobile loads in Poland is associated with the name of Jan Langer.[24]

Various types of methods can be used to analyze the dynamic effects of rail bridges as a result of high-speed train travel, including:

1) analytical methods based e.g. on modal analysis,

2) simplified methods, using the introduction of resonance excitation (DER Decomposition of the Resonance Excitation),

3) empirical methods based on real examples limited to several types of constructions,

4) analytical methods based on vehicle-bridge interaction.

Different methods of mathematical and physical accuracy are used in time methods - different theoretical models mapping a mobile train are used, e.g.

- HSLM (High Speed Load Model) standard models A and B,

- concentrated forces,

- masy skupione,

- single-mass oscillators,

- viscoelastic two-mass oscillators,

- flat sets of rigid mass discs and concentrated masses,

- spatial sets of shields and masses,

- other.

In addition to deterministic loads, due to the randomness of vibrations, many researchers use modeling of stochastic loads - consider vibrations in probabilistic categories, and therefore use a mathematical apparatus in the field of probability calculus and stochastic processes. [23]

The work compares the results for $15 \mathrm{~m}$ span bridges obtained by analytical methods for the following flat load models moving at a constant speed:

a) stream of concentrated forces [14]- P model, figure 2 ,

b) concentrated mass stream [14] - M model, figure 2,

c) one-mass oscillator stream [14] - $\mathrm{M}_{\mathrm{o}}$ model, figure $\mathbf{2}$,

d) two-mass oscillators stream [14]- $\mathrm{MM}_{\mathrm{o}}$ model, figure 2,

e) set of two rigid mass discs with linear viscoelastic first and second stage suspensions [17] - MBFS model, figure 3.

The above-mentioned five models are represented by a Japanese Shinkansen train (Figure 4) consisting of 8 repetitive rail vehicles, each $25 \mathrm{~m}$ long, with two independent two-axle bogies with $17.5 \mathrm{~m}$ wheelbase. [20] 
a)

b)
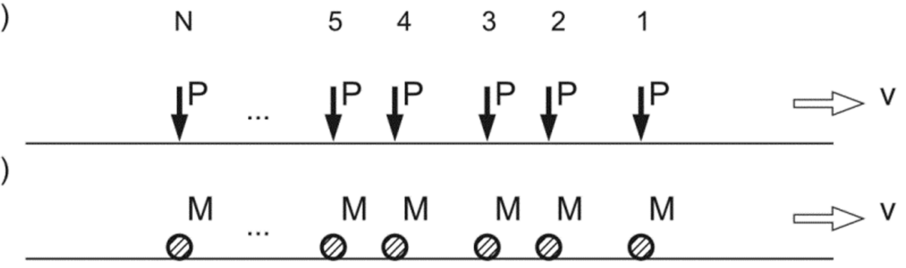

c)

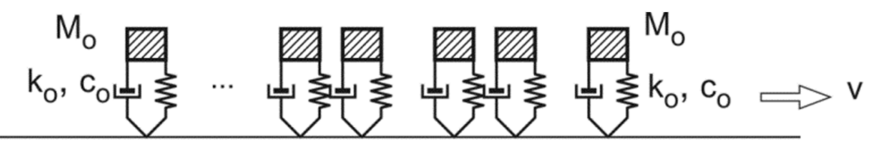

d)

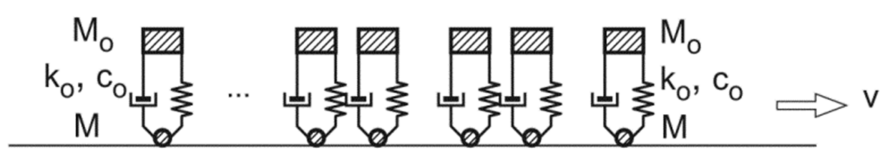

Fig. 2. Adopted mobile load models:

a) $\mathrm{P}$ model; b) $\mathrm{M}$ model; c) $\mathrm{M}_{\mathrm{o}}$ model; d) $\mathrm{MM}_{\mathrm{o}}$ model [14]
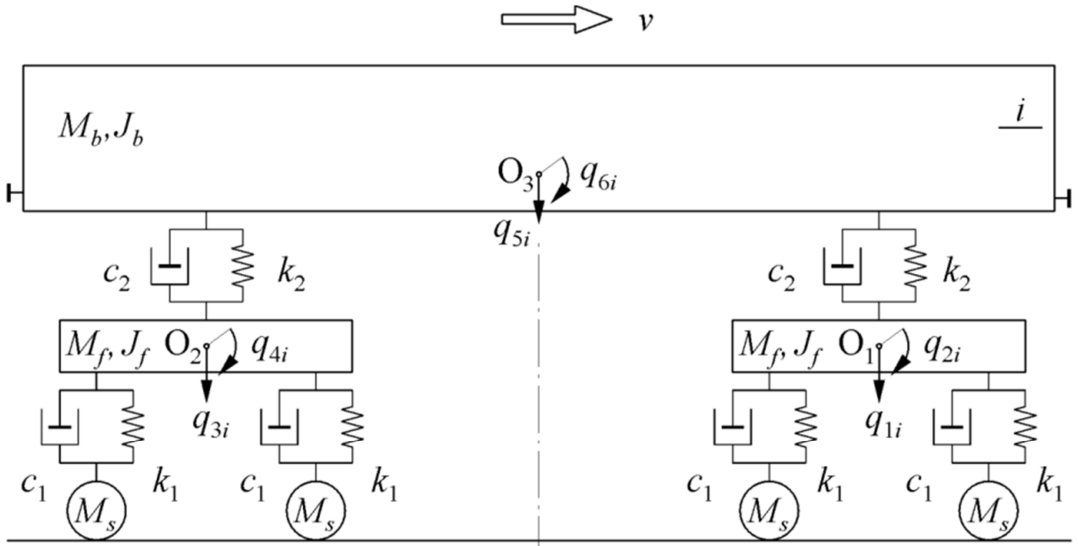

Fig. 3. Flat model of moving loads - MBFS model. [17]

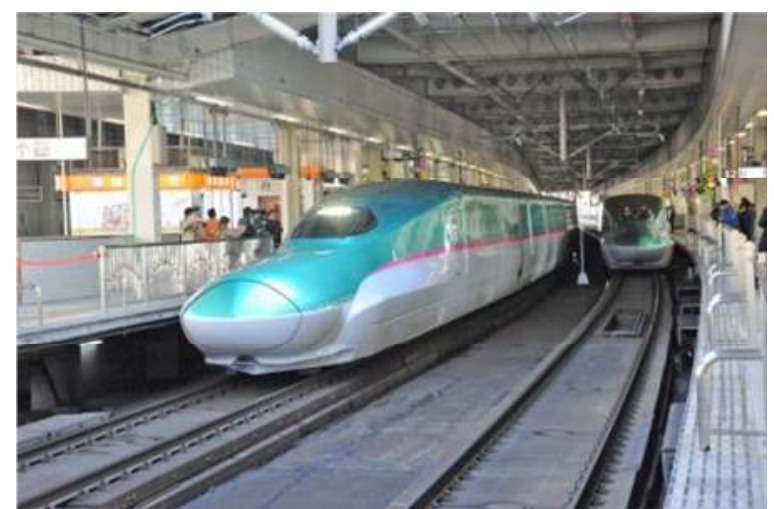

Fig. 4. An example of a Shinkansen train, [6]

The fifth model of the vehicle (Figure 3) is more complex than the others - it consists of four unsprung concentrated masses imitating wheelsets, two rigid mass discs mapping bogie frames including traction motors, and an upper rigid mass disc mapping the vehicle body. The vehicle model has four linear viscoelastic first stage suspensions and two-second stage suspensions. The system has 6 degrees of looseness.

The following main assumptions were made: 
- the physical model of the system is flat,

- a simplified model of a single-span railway bridge is a freely supported Euler beam,

- attenuation in the beam is Langer type (permanent decrement model) [8],

- the axis of a beam statically loaded with its weight is rectilinear,

- the track outside the beam is rectilinear and non-flexible,

- the rails are perfectly straight - no track unevenness,

- the system is physically and geometrically linear compartments,

- the load speed is constant,

- at the moment $t=0$ the system is in static equilibrium,

- a finite stream of $\mathrm{N}$ repetitive moving elements is considered, at intervals reflecting the axial distance of the bogies and the length of the vehicle (cyclic load),

- $\quad$ one-sided bonds between vehicle wheels and rails were taken into account $\left(\mathrm{MM}_{\mathrm{o}}\right.$ and MBFS models).

a)
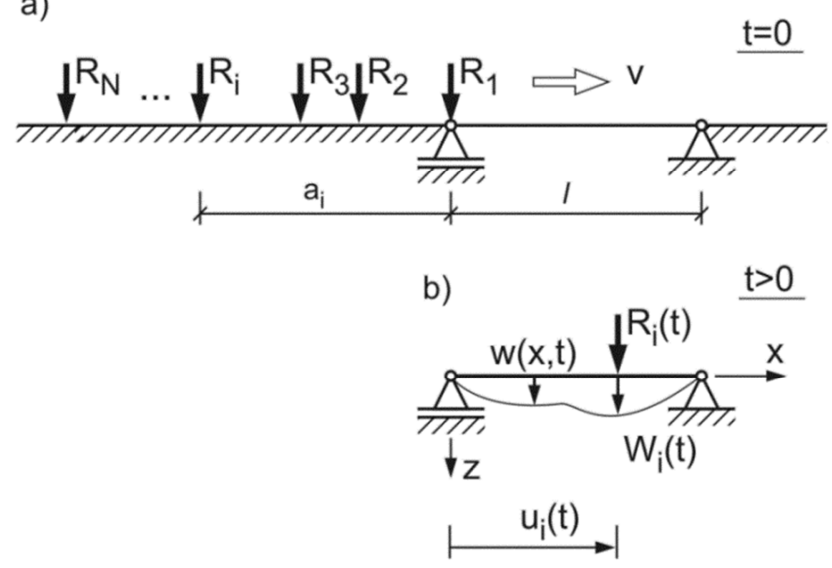

Fig. 5. Beam and moving load models:

a) system configuration at the initial moment, b) dynamic beam deflection $w(x, t)$ and the position of the interaction force $R_{i}(t)$

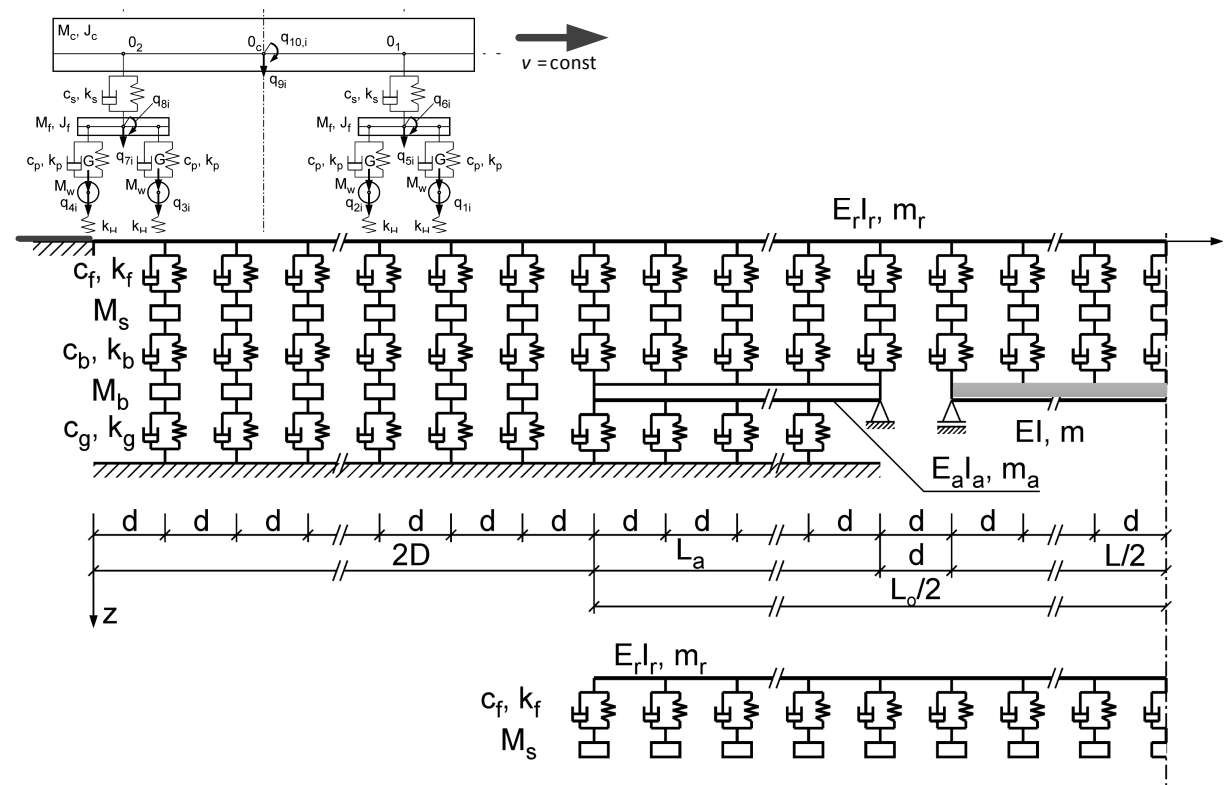

Fig. 6. Example system taking into account deformability of access zones

- contaminated scale [15] 
In the dynamic analysis of $\mathrm{M}_{\mathrm{o}}, \mathrm{MM}_{\mathrm{o}}$, MBFS models, interaction forces were introduced (Figure 5) between focused moving elements and the bridge beam (VBI - the vehicle-bridge interaction).

Movement equations were formulated in secret form, separately for the beam and moving load. Type II Lagrange equations for the beam and the d'Alembert principle for moving load were used. Matrix equations of subsystem motion were obtained, belonging to the class of ordinary, linear differential equations with constant coefficients:

$\mathbf{B} \ddot{\mathbf{q}}(t)+\mathbf{C} \dot{\mathbf{q}}(t)+\mathbf{K q}(t)=\mathbf{F}[\mathbf{R}(t), t]$

where:

$\mathbf{B}, \mathbf{C}, \mathbf{K}$ - matrices of inertia, damping, and rigidity,

$\mathbf{F}[\mathbf{R}(t), t]$ - generalized load vector dependent on the interaction force vector $\mathbf{R}(t)$ and time variable $\mathrm{t}$.

Matrix equations of motion of the system were formulated partly in an implicit form. Then they were numerically integrated using the Newmark average acceleration method with the parameters $\beta_{\mathrm{N}}=1 / 4, \gamma_{\mathrm{N}}=1 / 2$, developed into an implicit form [14]. An analysis of bending vibrations in the vertical plane of bridges was carried out.

As a result of dynamic analysis, the following conclusions were received:

1) Models $P$ and $M$ do not include suspension - no vehicle-structure interaction.

2) Model $M$ is rated as the least favorable because it shows large differences, both qualitative and quantitative, compared to other models.

3) The $P$ and $M_{o}$ models are close to reality, but there may be distortions in resonance states.

4) In the area of simplified train models, the $\mathrm{MM}_{\mathrm{o}}$ model is most similar to reality

5) Modeling of fast rail vehicles requires including unsprung masses, sprung masses and viscoelastic suspensions. The $\mathrm{MM}_{\mathrm{o}}$ model with these features is rather simplified. It is suggested to model separately wheelsets, sprung bogie frames, sprung vehicle bodies and first and second-order viscoelastic suspensions, e.g. MBFS model.

6) In the case of repetitive rail vehicles, resonance conditions may occur, therefore, the total number of vehicles and damping factors should be taken into account in dynamic simulations.

None of the above models took into account the deformability of the track in the access zones to the bridge. In works $[15,18]$, where a much more complex system (Figure 6) of a bridge track - mobile train (BTT system) was adopted, the enormous impact of this element on the analysis of the bridge as an effect under the influence of trains traveling at high speeds was proved. The results of the analysis presented in [1] confirm that the "track threshold inequality" due to a sudden change in trackbed stiffness must be taken into account.

\section{Conclusions}

Constant moving load models are widely used in dynamic analysis of railway bridges. However, using this simple model can overestimate the resonance response of a bridge with a simply supported beam pattern if the vehicle-bridge interaction (VBI) effects are ignored, especially for short spans. [25] To accommodate the VBI effects, Eurocode 1 [11] enables engineers to consider additional structural damping that depends on the bridge span. This method is the so-called Additional Damping Method (ADM), it was formulated to take into account the impact of the predicted interaction. It should be taken into account that the additional attenuation method can sometimes cause a dangerous prediction of the structure's response. [25]. 
In the paper [5] presenting a theoretical and experimental analysis of a bridge with a span width of $15.25 \mathrm{~m}$, the authors admitted that numerical models overestimate the maximum accelerations of the bridge structure. They argue that this is probably due to a lack of consideration of vehicle-design interactions that are most relevant in resonance. Such situations are less common in medium or long bridges. [5]

Small span railway bridges seem more problematic [21]. It is observed that the phenomenon of resonance occurs more often in short bridges [3,9]. It should be noted that the dynamic behavior is influenced not only by the bridge's structural properties but also by the track's dynamic properties, namely ballast, and rail as well as the dynamic properties of the vehicle, especially in bridges with short spans. These aspects result in particularly difficult to predict dynamic responses at the design stage of this type of structure [22].

Dynamic analysis of bridge structures is necessary for the event of resonance, i.e. a dangerous phenomenon that can occur as a result of high speeds and regularly spaced groups of train axles (load cyclicality). If the track unevenness is additionally present, excessive vibrations of the bridge plate may cause loss of wheel-rail contact, ballast destabilization, the occurrence of cracks and concrete crumbling as well as exceeding the stress limits of the bridge structure. Dynamic effects, including resonance, must always be taken into account when analyzing a railway bridge over which high-speed trains can travel. In the case of a cyclic stream of moving forces, states of force resonance may occur in the beam.

\section{Source materials}

[1] Bryja D., Popiołek A., Analiza drgań pojazdów kolejowych w trakcie ich przejazdu przez nierówność progową toru, Przegląd komunikacyjny, 9,2018, 68-72.

[2] Dyrektywa Parlamentu Europejskiego i Rady 2008/57/WE z dnia 17 czerwca 2008 r. w sprawie interoperacyjności systemu kolei we Wspólnocie (przekształcenie) - Dziennik Urzędowy Unii Europejskiej L 191/1.

[3] ERRI D-214/RP 9. Rail bridges for speeds $>200 \mathrm{~km} / \mathrm{h}$. Final report. Utrecht: European Rail Research Institute (ERRI); 1999.

[4] Fryba L., Dynamics of railway bridges. Academia, Praha, 1996.

[5] Galvin P., Romero A., Moliner E., Martinez-Rodrigo M.D., Two FE models to analyse the dynamic response of short span simply-supported oblique high-speed railway bridges: Comparison and experimental validation, Engineering Structures, 167, 2018, 48-64

[6] http://www.ns.szybkiekoleje.org.pl/, 2019-08-22

[7] Klasztorny M.: Dynamika mostów belkowych obciążonych pociągami szybkobieżnymi, WNT, Warszawa 2005.

[8] Langer J., Dynamika budowli, WPWr, Wrocław 1980.

[9] Museros P, Romero ML, Poy A, Alarcon E., Advances in the analysis of short span railway bridges for high-speed lines, Computers \& Structures, 80, 2002, 212 1-32

[10] PN-EN 1990-Eurocode 0 Podstawy projektowania konstrukcji, 2004.

[11] PN-EN 1991-2 Eurocode 1 Oddziaływania na konstrukcje. Część 2. Obciążenia ruchome mostów; 2007.

[12] PN-66/B-02015. Mosty, wiadukty i przepusty - obciążenia i oddziaływania.

[13] PN-85/S-10030. Obiekty mostowe. Obciążenia.

[14] Podwórna M., Dynamics of a bridge beam under a stream of moving elements. Part 1 Modelling and numerical integration, Structural Engineering \& Mechanics 38, 3, 2011, $283-300$.

[15] Podwórna M., Dynamic response of steel-concrete composite bridges loaded by highspeed train, Structural Engineering \& Mechanics, 62, 2, 2017, 179-196. 
[16] Podwórna M., Współczynniki dynamiczne ugięć pionowych w analizie numerycznej belkowych mostów kolejowych, Przegląd Komunikacyjny, 9,2017, 7-11.

[17] Podwórna M., Vertical vibrations of steel beam bridges induced by trains moving at high speeds. Part 1 - theory, Archives of Civil Engineering, 51, 2, 2005, 179-209.

[18] Podwórna M., Klasztorny M., Vertical vibrations of composite bridge / track structure / high-speed train systems. Part 3: Deterministic and Random Vibrations of Exemplary System, Bulletin of the Polish Academy of Sciences / Technical Sciences 62, 2, 2014, 305-320.

[19] Raport Unii Europejskiej - EU transport in figures 2018.

[20] Rebelo C. Simoes da Silva L. Rigueiro C. Pircher M., Dynamic behaviour of twin single-span ballasted railway viaducts - field measurements and modal identification. $\mathrm{J}$ Engineering Structures 30, 2008, 2460-9.

[21] Rocha J.M., Henriques A.A., Calçada R., Probabilistic safety assessment of a short span high-speed railway bridge, Engineering Structures 71, 2014, 99-111.

[22] Rocha J.M., Henriques A.A., Calcada R., Safety assessment of a short span railway bridge for high-speed traffic using simulation techniques Engineering Structures 40, 2012, $141-154$.

[23] Śniady P., Podstawy stochastycznej dynamiki konstrukcji, Wrocław, Oficyna Wydawnicza PWr ,2000.

[24] Szcześniak W., Ataman M., Przegląd publikacji polskich autorów z zakresu obciążeń ruchomych na konstrukcjach inżynierskich, Autobusy. Technika, Eksploatacja, Systemy Transportowe, 226, 12, 2018, 667-674.

[25] Yau J.D., Martínez-Rodrigo M.D., Doménech A., An equivalent additional damping approach to assess vehicle-bridge interaction for train-induced vibration of short-span railway, Bridges Engineering Structures, 188, 2019, 469-479.

[26] Zbiciak A., Oleszek R., Michalczyk R., Dynamic of an orthotropic railway bridge in the light of european standards, Archives of Civil Engineering LXII, 2, 2016, s.265-282

[27] Zobel H., Mossakowski P., Oleszek R. Analiza statyczna i dynamiczna mostu kolejowego nad rzeką Czarna w ciągu CMK. Inżynieria i Budownictwo 7-8/2013, 429435 . 